\title{
KOMPETENSI GURU DI ERA REVOLUSI INDUSTRI 4.0
}

\author{
Yudha Adrian $^{1}$, Rahidatul Laila Agustina ${ }^{2}$ \\ 1. Pendidikan Guru Sekolah Dasar STKIP PGRI Banjarmasin \\ yudhaadrian@Stkipbjm.ac.id (085651010726) \\ 2. Pendidikan Guru Sekolah Dasar STKIP PGRI Banjarmasin \\ rahidatul.agustina@Stkipbjm.ac.id (081322862916)
}

\begin{abstract}
ABSTRAK
Guru sebagai agen perubahan dituntut memiliki kompetensi pedagogik, kompetensi profesional, kompetensi kepribadian, dan kompetensi sosial. Kompetensi guru menjadi bekal dalam menghadapi perubahan zaman. Di era revoluasi industri 4.0, kompetensi guru tidak sebatas nampak pada kehidupan nyata, namun dapat pula dicitrakan di dunia maya atau virtual. Oleh karena itu, guru harus proaktif dalam memanfaatkan perubahan iptek yang terjadi saat ini. Empat kompetensi guru harus dipadukan dengan kemajuan teknologi sehingga dapat diterima dikalangan peserta didik, teman sejawat, dan masyarakat luas.
\end{abstract}

Kata Kunci: Guru, Kompetensi Guru, Revolusi Industri 4.0

\section{PENDAHULUAN}

Pendidikan Guru adalah orang yang paling berjasa membentuk kepribadian, intelektualitas, dan keterampilan setiap individu. Di tangan guru banyak profesi terbentuk. Setiap individu mendapatkan banyak bekal kehidupan di dunia ini. Guru memberikan pengetahuan dan keilmuan agar setiap individu menjadi pribadi yang dapat menghadapi masa depan yang gemilang.

Istilah "guru" sangatlah erat hubungannya dengan dunia pendidikan. Oleh karena itu, banyak makna istilah "guru". Dalam bahasa Inggris "guru" adalah teacher. Asal kata teacher adalah teach (mengajar). Jadi, guru adalah orang yang memberikan pengajaran kepada peserta didiknya.

Selain itu, guru merupakan orang yang memberikan pendidikan kepada peserta didiknya. Dalam kontek ini guru sebagai (educator) seorang pendidik yang bertanggung jawab terhadap peserta didiknya. Pendidik [1] adalah tenaga kependidikan yang memiliki kualifikasi pendidikan sebagai guru dan berpartisipasi dalam penyelenggaraan pendidikan. Oleh karena itu, seorang yang mempunyai tanggung jawab pekerjaan pendidik.

Di dunia pendidikan, peran guru sangatlah komplek guna mencerdaskan kehidupan bangsa Indonesia. Oleh karena itu, guru memiliki tugas yang sangat muali. Mangacu pada [2] pasal 1 ayat 1 disebutkan bahwa guru adalah pendidik profesional dengan tugas utama mendidik, membimbing, mengarahkan, melatih, menilai dan mengevaluasi peserta didik pada pendidikan anak usia dini jalur pendidikan formal, 
pendidikan dasar, dan pendidikan menengah. Undang-undang ini secara eksplisit menyatakan bahwa guru profesional harus membentuk karaktek peserta didik sesuai Pancasila dan UUD 1945. Selain itu, membentuk peserta didik yang cerdas dalam dan luas pengetahuannya. Peserta didik memiliki keterampilan dan kompetensi.

Dalam menjalankan tugas, guru harus memiliki kemampuan dan kompetensi dalam mengelola pendidikan dalam lingkup kelas, bahkan lingkup sekolah. Kompetensi [4] adalah keseluruhan pengetahuan, sikap, dan keterampilan. Mengacu pada PP no 74 tahun 2008, menyatakan bahwa guru harus memiliki empat kompetensi yaitu: 1) Kompetensi Pedagogik; 2) Kompetensi Kepribadian; 3) Kompetensi Profesional; dan 4) Kompetensi Sosial.

Kompetensi pedagogik merupakan kecakapan seorang guru dalam mentranformasi pengetahuan kepada peserta didik. Kompetensi pedagogik meliputi kecakapan guru dalam merancang perencanaan pembelajaran, melaksanakan pembelajaran, dan mengevaluasi hasil belajamur peserta didik sesuai dengan level pendidikan dan perkembangan peserta didik. Dalam merancang dan melaksanakan pembelajaran, seorang guru menerapkan teori-teori belajar sesuai dengan perkembangan zaman dan iptek.

Kompetensi kepribadian merupakan kemampuan guru dalam menjadi contoh dalam kehidupan di lingkungan sekolah, bahkan masyarakat. Guru menjadi cermin kehidupan bagi peserta didik. Arif dan bijaksana dalam menghadapi permasalahan di lingkungan sekolah dan masyarakat.

Kompetensi sosial meruakan kemampuan guru dalam berosisalisasi terhadap peserta didik, rekan kerja, dan lingkungan masyarakat. Kemampuan bersosialisasi menjadi indikator kemampuan guru dalam kompetensi sosial. Karena tanpa adanya kompetensi sosial, guru tidak akan mampu menyelesaikan tugasnya sebagai pengajar, pendidik, bahkan manajer di satuan pendidikan.

Kompetensi profesional merupakan kemampuan guru dalam menguasai pembelajaran secara luas dan mendalam. Penguasaan tersebut dalam konteks teoritis maupun praktis. Dengan kata lain, guru mampu menerapkan kaidah-kaidah teori belajar, sekaligus mempraktikkannya dalam proses pendidikan.

Urgensi kompetensi guru yang hidup di era revolusi industri 4.0 adalah kemampuan guru dalam mengembangkan kompetensi tersebut sesuai dengan perkembangan zaman. Oleh karena itu,menjadi hal menarik untuk membahas kompetensi guru di era revolusi industri 4.0.

\section{PEMBAHASAN}

Revolusi industri 4.0 memberikan dampak yang sangat pesat terhadap berbagai aspek kehidupan. Hal ini disebabkan teknologi informasi menjadi basis dalam kehidupan manusia. Dampak yang dirasakan saat ini adalah kemudahan dalam mengakses informasi dari berbagai sumber melalui jaringan internet. [6] Penggunaan daya komputasi dan data yang tidak terbatas (unlimited), karena dipengaruhi oleh perkembangan internet dan teknologi informasi yang menjadi urat nadi pergerakan dan konektivitas manusia. Internet menjadi primadona dalam segala hal. Sehingga 
manusia menggantungkan harapan pada koneksi internet. Dengan demikian, internet menjadi salah satu kebutuhan primer yang harus dimiliki oleh setiap individu.

Perkembangan teknologi yang sangat pesat menjadi guru dituntut harus up to date dalam menghadapi revolusi industri 4.0. Seorang guru haruslah melek terhadap revolusi teknologi informasi yang berkembang di era sekarang ini. Kondisi mukhtahir seperti saat ini hendaknya menjadi motivasi bagi guru agar mentranformasi informasi yang tersedia menjadi ilmu pengetahuan yang bermanfaat bagi peserta didik.

Di era sebelum revolusi industri, peran guru adalah sebagai sumber belajar bagi peserta didik. Guru menjadi orang yang paling mengetahui segala sesuatu tentang materi pembelajaran. Guru yang paling memahami setiap bagian materi pada sumber belajar. Buku paket menjadi sumber belajar utama yang dijadikan sumber belajar bagi guru. Oleh karena itu, pengetahuan guru akan sama dengan informasi yang terdapat pada buku. Bukan tidak mungkin, guru hafal materi yang terdapat pada buku pelajaran.

Di era revolusi industri 4.0, guru tidak lagi menjadi sumber belajar utama. Peran guru di era revolusi industri 4.0 bergeser menjadi pembimbing, pengarah, diskusi, dan pengukur kemajuan belajar siswa [7]. Dengan kata, guru hanya menjadi fasilitator dalam kegiatan pembelajaran. Guru hanyalah orang yang megarahkan peserta didik mencari sumber belajar melalui berbagai sumber. Sumber belajar utama yang akses oleh peserta didik internet. Peserta didik mudah mengidentifikasi berbagai materi pelajaran melalui mesin pencari GoogleTM. Satu kali klik, maka akan tersedia materi yang dicari oleh peserta didik. Materi tersebut mesti di sesuaikan dengan kompetensi yang harus dicapai. Oleh karena itu, peran guru menjadi fasilitator yang menyaring materi yang diakses oleh peserta didik, sehingga sesuai dengan kompetensi yang akan dicapai.

Untuk menyikapi revolusi industri 4.0, guru harus mengembangkan kompetensi seiring perkembangan teknologi dan informasi. Guru harus mampu memanfaatkan teknologi sebagai sarana pembelajaran. Guru dapat memanfaatkan aplikasi Rumah Juara Indonesia sebagai salah satu alternatif pembelajaran berbasis virtual. Guru meminta peserta didik untuk mencari materi sesuai dengan kompetensi yang akan dicapai. Selain itu, guru dapat memanfaatkan aplikasi Rumah Juara menjadi alat penilaian untuk peserta didik. Pada aplikasi Rumah Juara Indonesia terdapat latihan yang dapat digunakan oleh guru sebagai asesmen bagi peserta didik untuk mengukur ketercapain kompetensi.
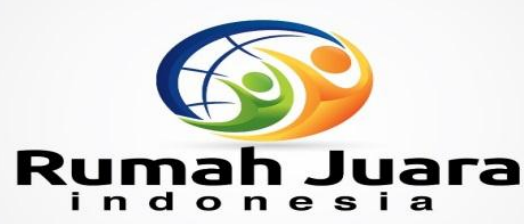

Gambar 1. Rumah Juara Indonesia 
Pelaksanaan evaluasi, guru dapat menggunakan aplikasi berbasis internet dan teknologi informasi. Aplikasi tersebut adalah Mung Exambro dan Google Form. Aplikasi Mung Exambro salah satu aplikasi yang tersedia di Playstore . Guru dapat mengakses aplikasi tersebut untuk digunakan sebagai alat asesmen berbasis smatphone. Pada aplikasi Mung Exambro, terdapat kolom pembaca link dan barkode yang digunakan untuk membuka soal-soal berbasis online tersebut. Kelebihan penggunaan aplikasi ini, peserta didik akan sulit untuk membuka browser, sehingga akan sulit untuk Googling mencari jawaban soal tersebut. Kekurangan aplikasi Mung Exambro, user wajib memiliki paket data untuk menghubungkan ke website penyedia soal.

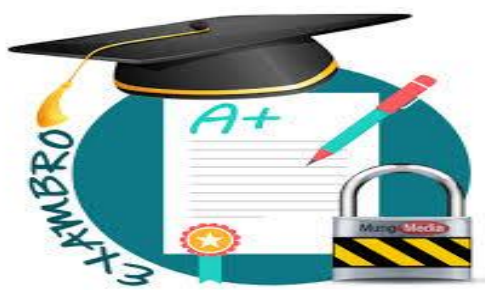

Gambar 2. Aplikasi Mung Exambro

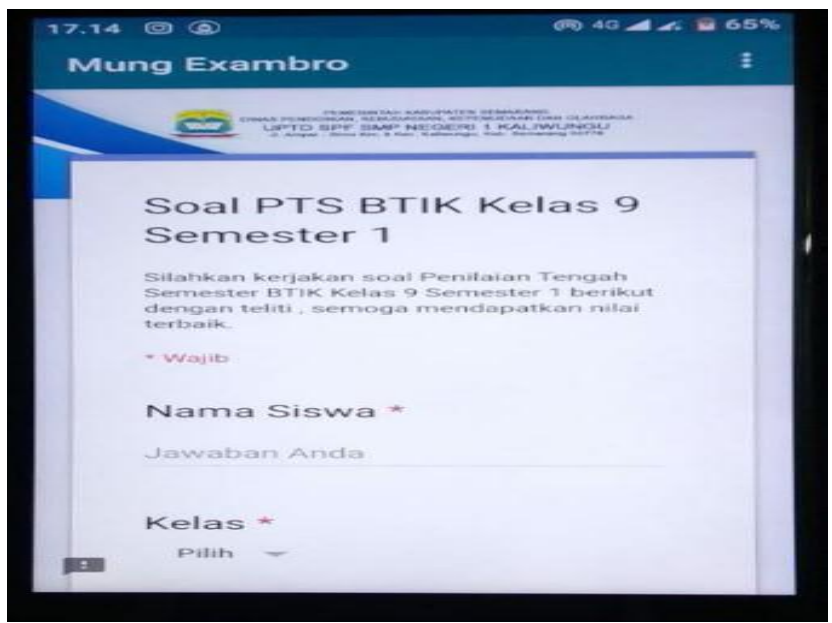

Gambar 3. Soal di Mung Exambro

Politik, kewajiban dan hak warga negara

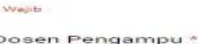

Dosen Pengampu -

Nama -

Kelas

NPM

Lamaban Amaso

Gambar 4. Soal Google Form 
Guru dapat memanfaatkan Google Form dalam melaksanakan evaluasi kepada peserta didik. Google Form adalah salah satu layanan yang disediakan oleh Google. Google dapat digunakan sebagai instrumen berbentuk tes, dan non-tes. Tampilannya pun sangat variatif sehingga peserta didik akan tertarik dalam melaksanakan soalsoal.

Soal yang dibuat menggunakan Google Form harus mentransformasi menjadi link. Link tersebut dapat digunakan untuk membuka soal yang telah di buatkan sebelumnya. Link tersebut dapat dibuka melalui aplikasi Mung Exambro. Selain itu, link dapat dibuka melalui browser bawaan pada smartphone.

Kelebihan penggunaan Google Form yaitu guru akan dengan mudah melihat jawaban siswa yang masuk melalui Google Drive. Jawaban dan nilai akan masuk bersamaan ke Google Drive. Nilai akan muncul jika soal yang dibuat melalui Google Form berbentuk pilihan ganda atau bentuk false/true serta dilengkapi dengan kunci jawaban. Sehingga, nilai akan menjadi nilai dengan bentuk format excel.dengan demikian, guru akan mudah untuk input nilai hasil pekerjaan peserta didik. Kekurangan penggunaan Google Form yaitu dalam penggunaannya memerlukan data untuk koneksi internet.

Pemanfaatan aplikasi berbasis internet dan iptek hanyalah salah satu cara yang dapat digunakan oleh guru untuk menyikapi revolusi industri 4.0. Kemajuan akses internet hanyalah salah satu dampak revolusi industri 4.0. Guru hendaknya menjadi pioner dalam membentuk pengetahuan, sikap, dan keterampilan peserta didik pada khususnya. Guru harus mempersiapkan peserta didik agar mampu menghadapi revolusi industri 4.0 atau abad 21.

Pemanfaatan internet dan Iptek hanyalah tuntutan sebagai guru profesional yang memiliki kompetensi profesional. Artinya, guru mampu bersaing dalam mengolah, mentrasformasi, dan menghasilkan pengetahuan sesuai dengan tuntutan zaman. Perubahan zaman semakin canggih menuntut guru agar lebih ekstra dalam mengolah informasi dari berbagai sumber terutama internet. Hal ini yang menjadi aktualisasi kompetensi profesional dan pedaogik guru di era revolusi 4.0.

Pada era revolusi industri 4.0 tujuan utama pembelajaran adalah membangun kemampuan belajar peserta didik dan mendukung perkembangan mereka menjadi pebelajar sepanjang hayat,aktif, pebelajar yang mandiri; oleh karena itu guru perlu menjadi 'pelatih pembelajaran' sebuah peran yang sangat berbeda dengan guru kelas tradisional [5].

Tuntutan guru tidak hanya menguasai pengetahuan yang akan mereka transformasi kepada peserta didik, melainkan bagaimana membuat peserta didik memahami, menghayati, dan menghasilkan suatu keterampilan yang menunjang di era revolusi industri 4.0 atau abad 21. Jadi, kompetensi profesional guru tidak hanya menuntut guru untuk menguasai bidang pengetahuan dan keahliannya dalam mengolah materi, melainkan mempersiapkan peserta didik dalam menghadapi era 
digital. Era dimana setiap individu harus bersaing dengan otomasi kehidupan yang serba canggih dan modern.

Teknologi dan kemuktarhiran perangkat komputer memicu revolusi industri 4.0 berdampak pada penggantian, pemangkasan, dan perubahan lapangan kerja [6]. Hal ini perlu penanganan serius bagi pemerintah. Guru sebagai ujung tombak roda pengembangan pendidikan seyogyanya membekali peserta didik keterampilan yang harus di miliki di era revolusi industri 4.0.

Secara umum, terdapat 18 jenis keterampilan yang harus dimiliki untuk menghadapi era revolusi industri 4.0. keterampilan tersebut sebagai berikut: 1) kemampuan persepsi sensorik 2) kemampuan mengambil informasi, 3) kemampuan mengenali polapola/kategori-kategori, 4) kemampuan membangkitkan pola/kategori baru, 5) kemampuan memecahkan masalah, 6) kemampuan memaksimalkan dan merencanakan, 7) kreativitas, 8) kemampuan mengartikulasikan/menampilkan output, 9) kemampuan berkoordinasi dengan berbagai pihak, 10) kemampuan menggunakan bahasa untuk mengungkapkan gagasan, 11) kemampuan menggunakan bahasa untuk memahami gagasan, 12) kemampuan penginderaan sosial dan emosional, 13) kemampuan membuat pertimbangan sosial dan emosional, 14) kemampuan menghasilkan output emosional dan sosial, 15) kemampuan motorik halus/ketangkasan, 16) kemampuan motorik kasar, 17) kemampuan navigasi, 18) kemampuan mobilitas [3].

Keterampilan tersebut akan mudah diperoleh melalui proses pendidikan dan peran guru sebagai fasilitator agen perbubahan peserta didik. Oleh karena itu, guru harus mendayaguanakan empat kompetensi yang wajib mereka miliki agar mampu memfasilitasi peserta didik menjadi pribadi yang tanggap dalam menghadapi era revolusi 4.0. dengan demikian, kompetensi guru sangatlah penting guna menujang karir guru di dunia pendidikan. Hal yang tidak kalah penting adalah empat kompetensi guru ditambah kemampuan pengaplikasian iptek akan menunjang kompetensi guru dalam mendidik, membelajarkan, dan bahkan membentuk keterampilan peserta didik.

Kompetensi kepribadian guru di era revolusi 4.0 dipaduakan dengan perkembangan Iptek. Guru dapat mencitrakan kehidupan pribadinya melalui update status media sosial. Status tersebut harus berkesan, bermakna, dan memberikan pesan kebaikan bagi yang melihat status tersebut. Bahasa intelektual digunakan dalam update status. Hal ini dilakukan dengan harapan teman-teman di media sosial dapat melihat, mengilhami, dan mengikuti ungkapan-ungkapan yang dibuat. Dengan demikian, media sosial menjadi media penyampai pesan dari guru kepada peserta didik.

Kompetensi sosial yang dimiliki oleh guru dapat diaplikasikan melalui penggunaan media sosial. Guru bersosialisasi dengan teman sejawat,orang tua peserta didik, bahkan dengan peserta didik melalui media sosial. Media sosial menjadi 
jembatan penghubung komunikasi antara guru dengan masyarakat virtual. Dengan demikian, media sosial menjadi jembatan online bagi penggunannya, khususnya peserta didik dan guru untuk mempermudah berpartisipasi, berbagi, serta menciptakan jaringan sosial didunia virtual [8].

\section{SIMPULAN}

Peran guru di era revolusi industri sangatlah penting dalam mempersiapkan manusia pada umumnya, dan peserta didik pada khususnya. Persiapan yang dilakukan oleh guru melalui kegiatan pembelajaran yang bermanfaat. Selain itu, guru memanfaatkan kemampuan dalam mempersiapkan pendidikan yang berorientasi pada iptek. Hal yang tidak kalah penting, guru seyogyanya mempersipkan 18 keterampilan abad 21. Dengan harapan, peserta didik mampu bersaing dengan individu lainnya melalui kegiatan pembelajaran sesuai dengan era revolusi 4.0.

\section{DAFTAR RUJUKAN}

[1] Y. Adrian, "Kompetensi Guru Sekolah Dasar," Lentera Jurnal Ilmiah Kependidikan, pp. 85-97, 2017.

[2] Undang-Undang RI No.14, Guru dan Dosen, Jakarta: Depdiknas, 2005.

[3] S. Yamnoon, Education 4.0, Teaching and Learning in 21 th Century, Lobbury Thailand: Thepstri Rhajabat University, 2018.

[4] M. Surya, Psikologi Pembelajaran dan Pengajaran, Bandung : Pustaka Bani Qusairy, 2004.

[5] S. Zubaidah, "Keterampilan Abad Ke-21: Keterampilan yang Diajarkan Melalui Pembelajaran," in Seminar Nasional Pendidikan dengan tema "Isu-isu Strategis Pembelajaran MIPA Abad 21, Sintang, 2016.

[6] I. Sujadi, "Peran Pembelajaran Matematika pada Penguatan Nilai Karakter Bangsa di Era Revolusi Industri 4.0," in Seminar Nasional Matematika Universitas PGRI Madiun, Madiun, 2018.

[7] M. Hampson, A. Patton and L. Shanks, Ten Ideas for 21st Century Education, London: Innovation Unit, 2011.

[8] W. S. R. Putri , N. R. Nurwati and M. S Budarti, "Pengaruh Media Sosial Terhadap Perilaku Remaja," Prosiding Penelitian \& Pengabdian Kepada Masyarakat, vol. 3, pp. 47-51, 2016. 